\title{
RELACJE SPOŁECZNE OSÓB NIESEYSZĄCYCH I SŁABOSŁYSZĄCYCH W ŚRODOWISKU PRACY
}

\section{Wprowadzenie}

Satysfakcja z pracy nie jest zależna jedynie od poziomu subiektywnego zadowolenia z wykonania określonych zadań, poczucia autonomii, możliwości awansowania, znaczenia danej pracy dla innych ludzi czy też wynagrodzenia. Dobra atmosfera, pozytywne relacje interpersonalne i poczucie przynależności do wspólnoty osób pracujących $\mathrm{w}$ danym miejscu są częstokroć określane jako decydujące o zadowoleniu z wykonywanej pracy. Poświadczają ten fakt także badania naukowe: Frederick P. Morgeson i Stephen E. Humphrey (2006) dzięki pracom badawczym przeprowadzonym wśród ponad 500 pracowników różnego szczebla stwierdzili wręcz, że poziom zadowolenia $\mathrm{z}$ relacji społecznych w środowisku pracy ma znacznie większy wpływ na poczucie zadowolenia z aktywności zawodowej niż jej rodzaj czy też wynagrodzenie.

Celem artykułu jest ukazanie specyfiki i jakości relacji społecznych doświadczanych przez osoby niesłyszące i słabosłyszące w miejscu pracy. Posłuży temu zarówno analiza literatury przedmiotu, jak i prezentacja własnych badań przeprowadzonych w grupie 31 pracujących osób $\mathrm{z}$ wadą słuchu uczestniczących w projekcie „Przełamując ciszę”. Było to szkoleniowo-stażowy program kompleksowej aktywizacji zawodowej osób niesłyszących opracowany w celu zwiększenia aktywności zawodowej osób z deficytami słuchu zamieszkałych na terenie województwa lubelskiego. Poprzez szkolenia oraz sześciomiesięczne staże odbywane w zakładach pracy dostosowanych do preferencji uczestników, osoby niesłyszące i słabosłyszące mogły doskonalić kompetencje kluczowe, zwłaszcza informatyczne i językowe, oraz poszerzać wiedzę na temat własnego potencjału osobowościo-

* Ewa Domagała-Zyśk; Katolicki Uniwersytet Lubelski Jana Pawła II, Al. Racławickie 14, 20-950 Lublin; tel. + 488144541 01; e-mail: ewadom@kul.pl 
wego i zawodowego. Zakładano, że przyczyni się to do zwiększenia motywacji do podejmowania aktywności zawodowej, jak również zdobycia doświadczenia zawodowego, które ułatwi utrzymanie się na rynku pracy.

\section{Osoby niesłyszące i słabosłyszące na współczesnym rynku pracy}

Międzynarodowa Organizacja Pracy określa, że za osobę niepełnosprawną należy uznać osobę, której możliwości uzyskania i utrzymania odpowiedniego zatrudnienia oraz awansu zawodowego są znacznie ograniczone w wyniku ubytku zdolności fizycznych lub umysłowych, właściwie orzeczonego (Konwencja nr 159 Międzynarodowej Organizacji Pracy). Praca jest niezbędnym elementem życia osoby dorosłej, ponieważ pozwala nie tylko na zaspokojenie potrzeb bytowych, lecz także daje satysfakcję, strukturyzuje czas, pozwala na nawiązywanie pozarodzinnych relacji społecznych (Majewski, 2006, 2007). $\mathrm{Z}$ tego względu podejmowanych jest wiele działań badawczych i praktycznych mających na celu przygotowanie osób z niepełnosprawnością do funkcjonowania w środowisku pracy (Ustawa z dnia 27 sierpnia 1997 r. o rehabilitacji zawodowej i społecznej oraz zatrudnianiu osób niepełnosprawnych). W procesie nazywanym rehabilitacją zawodową wyróżniono pięć etapów (Kowalik, 2007, s. 139-141): (1) aktywizację przedprodukcyjną, (2) diagnozę potencjału rehabilitacyjnego, (3) bezpośrednie przygotowanie do pracy, (4) dostosowanie warunków i stanowiska pracy do potrzeb osoby z niepełnosprawnością oraz (5) zatrudnienie i doskonalenie zawodowe. Efektem edukacji i rehabilitacji zawodowej powinno być więc podjęcie przez osobę z niepełnosprawnością pracy odpowiadającej jej kwalifikacjom, którą mogłaby wykonywać w poczuciu zadowolenia.

Szczegółowe dane o zatrudnieniu osób niesłyszących i słabosłyszących (określonych jako osoby z problemami w słyszeniu, nawet przy zastosowaniu aparatu słuchowego) przedstawia raport GUS: Osoby niepetnosprawne na rynku pracy w 2011 (2012). Dowiadujemy się z niego, że w Polsce mieszka 115 tys. osób w wieku od 15 do 64 lat korzystających z aparatów słuchowych. Najwięcej osób nosi aparaty po 50. roku życia, zatem można przypuszczać, że są to osoby ogłuchłe (78 tys.). Znacznie rzadziej korzysta się z aparatów słuchowych w młodszym wieku: 16 tys. osób w wieku od 15 do 34 lat i 18 tys. w wieku 35-49 lat. W całej analizowanej grupie 7 tys. osób ma wykształcenie wyższe, 22 tys. - policealne i średnie zawodowe, 6 tys. - średnie ogólnokształcące, 49 tys. - zasadnicze zawodowe, a 30 tys. - gimnazjalne lub niższe. Spośród analizowanej populacji pracuje tylko 33 tys. osób, status bezrobotnego ma 7 tys., biernych zawodowo jest zaś aż 75 tys. osób. Raport wskazuje, że czynnikami zniechęcającymi do podjęcia pracy są przede wszystkim: konieczność ciągłego dokształcania się, zmianowy charakter pracy, dojazdy, wymóg bezpośredniego kontaktu z klientem, niemożność pogodzenia życia rodzinnego z pracą oraz obawa przed izolacją społeczną w miejscu pracy. 
Zaprezentowany obraz jest zdecydowanie pesymistyczny i wskazuje na konieczność pilnych zmian. Stan wieloletniej bierności zawodowej niesie ze sobą katastrofalne skutki dla samej osoby z niepełnosprawnością, jej najbliższych, ale też dla całego społeczeństwa (Szczupał, 2004; Majewski, 2005). Z tego względu duże znaczenie społeczne mają badania naukowe i działania praktyczne stawiające sobie za cel poznanie sytuacji zawodowej osób z wadą słuchu, określenie doświadczanych przez nich barier i możliwych form wspierania tej grupy osób na rynku pracy.

Badania nad tożsamością zawodową osób słabosłyszących i niesłyszących prowadził w grupie 30 osób Tomasz Piekot (2011). Analiza wypowiedzi badanych prowadzi do wielu istotnych wniosków, głównie wiążących się z tym, że młodzi ludzie $\mathrm{z}$ wadą słuchu muszą w bardziej samodzielny sposób niż ich rówieśnicy odnaleźć się na rynku pracy. Wynika to z faktu, że większość z tych osób ma słyszących rodziców, którzy nie mogą być dla swoich dzieci wzorcami w zakresie wyboru zawodu. Młodzież biorąca udział w przytaczanych badaniach planowała co prawda wybór ścieżki zawodowej podobnej do tej obranej przez rodziców, zwłaszcza matki (np. nauczyciel, logopeda, policjant), nie uwzględniając jednak przeszkód w wykonywaniu tych zawodów wynikających z wady słuchu. Osoby niesłyszące i słabosłyszące nie są aktywne w poszukiwaniu pracy - nie pracują w trakcie nauki w szkole czy na uczelni, oczekując od instytucji edukacyjnej przygotowania do rozpoczęcia aktywności zawodowej (tamże, s. 21), natomiast gdy nie znajdują pracy w wyuczonym zawodzie - pozostają bezrobotne. Trudno jest im zaakceptować konieczność uzupełnienia przygotowania zawodowego. Pytane o trudności w znalezieniu pracy, badane osoby wskazywały zarówno na samych własne cechy (lenistwo, niechęć do przyjmowania odpowiedzialności, naiwność, niecierpliwość, impulsywność w podejmowaniu decyzji o rezygnacji), jak i na czynniki środowiska (brak sygnałów świetlnych ułatwiających komunikację, zbyt ciężką pracę, brak czytelnych instrukcji, ale i informacji zwrotnych, np. pochwał ze strony przełożonych).

Bariery utrudniające osobom niesłyszącym i słabosłyszącym funkcjonowanie w środowisku pracy zostały przeanalizowane w artykule Ewy Domagała-Zyśk (2010). W badaniach uczestniczyli absolwenci studiów wyższych mający poważne trudności w słyszeniu (uszkodzenie słuchu $90 \mathrm{~dB}$ lub większe, $N=11$ ). Wskazywali oni, że główną barierą jest brak zrozumienia, którego doświadczają osoby z wadą słuchu w społeczeństwie ( $66 \%$ odpowiedzi), wada słuchu sama w sobie (58\%) oraz problemy w komunikacji z przełożonymi, współpracownikami i klientami (58\%). Wśród czynników utrudniających aktywność zawodową wymieniano także mniejsze kompetencje osób z wadą słuchu, wynikające z wyboru nieodpowiedniej ścieżki kształcenia lub też niższego poziomu wykształcenia, oraz cechy osobowości, które mogą przeszkadzać w pracy, takie jak nieśmiałość, poczucie niskiej wartości, bierność. 
W kolejnym artykule dotyczącym pracy osób z wadą słuchu Domagała-Zyśk (2014) badała przekonania o aktywności zawodowej wyrażane przez pracujące osoby z wadą słuchu. Analiza wyników pozwala stwierdzić, że badane osoby niesłyszące i słabosłyszace $(N=31)$ w wysokim stopniu cenią pracę zawodową. Uważają, że nadaje ona sens ich życiu, rozwija osobowość oraz jest źródłem szacunku ze strony innych osób. Szczególne znaczenie mają odpowiedzi na pytania dotyczące określenia cech dobrej pracy; badane osoby wskazały, że najbardziej istotne są czynniki społeczne: dobra atmosfera w miejscu pracy, uznanie i szacunek wyrażane przez współpracowników oraz dobre z nimi kontakty. Wśród najważniejszych pięciu cech dobrej pracy znalazły się także: zgodność z zainteresowaniami oraz stanowienie źródła szacunku odczuwanego ze strony rodziny. Warto zauważyć, że owe pięć cech było dla badanych osób istotniejsze niż takie czynniki, jak niski stopień trudności zadań, możliwość awansu czy dogodny dojazd.

Liczne badania nad sytuacją zawodową osób niesłyszących i słabosłyszacych prowadzone są także w innych krajach (przegląd tych badań dostępny jest w: Domagała-Zyśk, 2010, 2013, 2014). Zagraniczne, a zwłaszcza amerykańskie prace badawcze koncentrują się przede wszystkim na poszukiwaniu i ocenie odpowiednich form dostosowania miejsc pracy, prowadzącego do tego, by osoba z wadą słuchu czuła się w nich bezpieczna i miała pełny dostęp do informacji (Geyer, Schroedel, 1999; Foster, MacLeod, 2004; Kramer, 2008). Badania potwierdzają także zmiany pokoleniowe: współcześnie osoby niesłyszące i słabosłyszące nie godzą się na kształcenie w zakresie prostych zawodów wymagających umiejętności manualnych, lecz mają takie same oczekiwania i aspiracje zawodowe jak ich słyszący rówieśnicy (Punch, Creed, Hyde, 2005).

\section{Znaczenie relacji interpersonalnych w środowisku pracy dla osób niesłyszących i słabosłyszących}

Relacje interpersonalne odgrywają w opinii osób z niepełnosprawnością kluczową rolę w ocenie jakości miejsca pracy. Wskazuje na ten fakt większość przeprowadzonych w tym zakresie prac badawczych. Niestety, niewiele jest badań dotyczących wyłącznie osób niesłyszących i słabosłyszacych (Świdziński, 2014; Dunaj, 2014; Maciejska-Roczan, 2011), dlatego w prezentowanym tu przeglądzie zawarto także wnioski z badań prowadzonych wśród osób z niepełnosprawnością w ogóle, gdzie osoby z wadą słuchu stanowiły tylko część badanej grupy (Mikulski, Kurzynowski, 2004; Sobczak, 2007; Radecki, 2007; Barczyński, Radecki, 2008; Brzezińska, Piotrowski 2008).

W ramach projektu „Identyfikacja potrzeb osób niepełnosprawnych w zakresie aktywizacji zawodowej" zbadano 108 osób z niepełnosprawnością; osoby z zaburzeniami słuchu i mowy stanowiły 11\% tej populacji (Barczyński, Radecki, 2008). Uczestnicy badań wskazali, że ich potrzeba podjęcia pracy wynika 
zarówno ze względów ekonomicznych (84\%), jak i z potrzeby kontaktu z innymi ludźmi (63\%) i chęci bycia potrzebnym (61\%). Relacje interpersonalne były bardzo ważne także dla $45 \%$ osób $\mathrm{z}$ różnymi niepełnosprawnościami badanych przez Annę I. Brzezińską i Konrada Piotrowskiego (2008).

Poziom zadowolenia osób z niepełnosprawnością z pracy zawodowej przedstawiono także w raporcie pt. „Zadowolenie osób niepełnosprawnych z pracy”. W badaniu uczestniczyły 1003 osoby z terenu całej Polski, jednak było wśród nich tylko $5 \%$ osób $\mathrm{z}$ wadą słuchu. Ponieważ tylko niektóre z wyników przedstawiono z uwzględnieniem rodzaju niepełnosprawności, wartość tego raportu dla poznania sytuacji grupy osób $\mathrm{z}$ wadą słuchu jest ograniczona. $\mathrm{Z}$ danych można jednak odczytać, że pracownicy niesłyszący i słabosłyszący są zadowoleni ze swojego miejsca pracy: $79 \%$ poleciłoby je innym osobom, $58 \%$ wyraża przekonanie, że nie grozi im zwolnienie z pracy, i tylko $2 \%$ nie podjęłoby ponownie pracy, którą obecnie wykonują. Jednocześnie badane osoby wskazują na szereg problemów doświadczanych w miejscu pracy: brak jasno zdefiniowanego zakresu obowiązków (11\%) oraz brak świadomości przysługujących im uprawnień (np. 48\% nie wiedziało o możliwości finansowania składek na ubezpieczenie indywidualne). Kolejne wyniki pokazują, że badane osoby cenią możliwość nieświadczenia pracy w godzinach nadliczbowych $(79 \%)$ i w porach nocnych (77\%) oraz pozytywnie wypowiadają się na temat dodatkowych dni urlopu wypoczynkowego (97\%). Badane osoby przyznały także, że są zadowolone z pracy takiej, jaką mają, i nie odczuwają potrzeby, by praca była bardziej interesująca.

$\mathrm{W}$ poszerzaniu zakresu zatrudnienia osób $\mathrm{z}$ wadą słuchu istotne znaczenie mają postawy pracodawców. Były one badane w ramach projektu „Rehabilitacja i zatrudnienie osób niepełnosprawnych na otwartym rynku pracy" (Mikulski, Kurzynowski, 2004). Wyniki raportu wskazują, że polscy pracodawcy (badana grupa liczyła 700 osób) mają zasadniczo pozytywny stosunek do osób z niepełnosprawnością, uważają je za życzliwe (45\%) i skromne (43\%). Zatrudniający osoby niepełnosprawne twierdzą, że są one tak samo wydajne jak inni (75\%), a ich potencjał jest odpowiednio wykorzystywany i rozwijany np. poprzez ofertę szkoleniową identyczną z tą, jaką oferuje się pracownikom sprawnym. W odniesieniu do relacji społecznych ponad $94 \%$ pracodawców sądzi, że osoby niepełnosprawne są $\mathrm{w}$ ich firmie traktowane tak samo jak inni pracownicy. W tym samym raporcie wskazano także, że pracodawcy, którzy do tej pory nie zatrudniali osoby z niepełnosprawnością, mają znacznie bardziej negatywne postawy wobec ich możliwości jako pracowników. Uważają, że będą one mniej wydajne, niżej oceniają ich możliwości rozwoju zawodowego oraz rzadziej postrzegają je jako osoby życzliwe i skromne.

Problem postaw pracodawców analizowała także Ewa Gorczycka (2000), prowadząc badania wśród pracodawców z zakładów pracy chronionej. Wyniki wskazują, że najchętniej zatrudnialiby oni osoby po zawale serca (55\% wskazań) lub niedosłyszące (40\%), najmniej chętnie natomiast przyjmują do pracy osoby 
z chorobami psychiatrycznymi, upośledzeniem umysłowym, epilepsją oraz głuchotą (po 5\% wskazań).

Przytaczany już raport „Rehabilitacja i zatrudnienie osób niepełnosprawnych na otwartym rynku pracy" (Mikulski, Kurzynowski, 2004) przedstawia także opinie niepełnosprawnych pracowników. Zwracają oni uwagę na trudności wiążące się przede wszystkim z niskimi zarobkami i brakiem dostosowań miejsca pracy do ich potrzeb, ale jednocześnie bardzo wysoko oceniają relacje społeczne w miejscu pracy: ponad $80 \%$ ma tam przyjaciół lub bliskich znajomych, na pomoc współpracowników może liczyć $76 \%$ badanych. Uważają oni także, że są tak samo traktowani przez przełożonych (87\%), jak i współpracowników (78\%).

\section{Metodologia badań własnych}

Motywem podjęcia badań nad rodzajem i jakością relacji społecznych osób niesłyszących i słabosłyszących w środowisku pracy były cytowane wcześniej wyniki (Domagała-Zyśk, 2014) wskazujące na pierwszoplanowe znaczenie dla osób $\mathrm{z}$ wadą słuchu kwestii atmosfery oraz relacji ze współpracownikami w miejscu pracy.

\section{Cel i pytania badawcze}

Przeprowadzone badania własne miały za cel określenie zakresu i jakości relacji społecznych osób niesłyszących i słabosłyszących doświadczanych w środowisku pracy. Szczegółowe problemy badawcze sformułowano w postaci następujących pytań: 1. Jaki jest ogólny poziom zadowolenia $\mathrm{z}$ wykonywanej pracy? 2. Jaki jest zakres trudności doświadczanych w zakresie komunikacji? 3. Jaka jest jakość relacji społecznych z przełożonymi i współpracownikami?

\section{Metody i techniki badań}

W badaniu zastosowano metodę sondażu diagnostycznego, wykorzystując jako główne narzędzie Skale jakości relacji społecznych osób niestyszących $i$ słabostyszacych $w$ środowisku pracy własnej konstrukcji. Składa się ona z 30 twierdzeń, które respondent ocenia na pięciostopniowej skali. Zawiera cztery części, dotyczące kolejno: (1) oceny pracy, (2) oceny poziomu własnych kompetencji zawodowych, (3) oceny zakresu trudności w komunikacji ze słyszącymi współpracownikami i przełożonymi oraz (4) jakości relacji społecznych.

\section{Charakterystyka badanych osób}

W badaniach wzięło udział 31 osób z uszkodzonym narządem słuchu. Była to ta sama grupa badawcza, która uczestniczyła w cytowanych wcześniej badaniach dotyczących przekonań o pracy zawodowej (Domagałą-Zyśk, 2014): 10 mężczyzn $(32,26 \%)$ i 21 kobiet $(67,74 \%)$, którzy w czasie prowadzenia prac badawczych byli stażystami w projekcie „Przełamując ciszę”. Prawie połowa z nich ukończyła stu- 
dia wyższe (14 osób - 45,16\%), pozostałe 17 osób było absolwentami szkół średnich (54,84\%); należy zatem zauważyć, że ich poziom wykształcenia był wyższy niż przeciętny poziom wykształcenia osób $\mathrm{z}$ wadą słuchu. Badani reprezentowali różne stopnie uszkodzenia słuchu: lekkie (6 osób - 19,35\%), umiarkowane (5 osób - 16,13\%), znaczne (6 osób - 19,35\%) i głębokie (13 osób - 41,93\%). Prawie połowa, bo 14 osób (45,16\%), określiła siebie jako „niesłyszących”, natomiast 17 osób $(54,84 \%)$ identyfikowało się z terminem ,słabosłyszący”. Zdecydowana większość badanych pochodziła z rodzin słyszących, tylko w dwóch rodzinach jeden z rodziców był osobą niesłyszącą, natomiast $\mathrm{w}$ jednej z rodzin nie słyszeli oboje rodzice. Badani określali swoje uszkodzenie słuchu najczęściej jako prelingwalne, powstałe przez 2. rokiem życia - odpowiedziało tak 25 osób. W przypadku jednej osoby uszkodzenie nastąpiło $\mathrm{w}$ 7. roku życia, natomiast $\mathrm{w}$ pięciu sytuacjach wada miała charakter postlingwalny.

Większość badanych w komunikacji posługiwała się mową (25 osób $80,65 \%)$, w tym mową wspieraną odczytywaniem z ust - 14 osób $(45,16 \%)$. Osiem osób $(25,81 \%)$ w komunikacji używało języka migowego, natomiast cztery $(12,90 \%)$ korzystały z systemu językowo-migowego. Cztery osoby $(12,90 \%)$ w komunikacji posługiwały się często pismem, a jedna używała fonogestów. Badani w zdecydowanej większości są absolwentami szkół ogólnodostępnych: podstawowych (21 osób - 67,74\%), gimnazjów (17 osób - 54,84\%) i liceów (23 osoby - 74,19\%). Część z nich chodziła do szkół integracyjnych (po 6 osób 19,35\% - na każdym poziomie edukacji), nieliczne osoby chodziły do szkół i ośrodków specjalnych (podstawowych: 4 osoby - 12,90\%, gimnazjum: 3 osoby $-9,68 \%$, liceum: 2 osoby $-6,45 \%)$.

\section{Analiza wyników badań}

Oceniając wykonywaną przez siebie pracę, badane osoby mogły określić jej podstawowe zalety oraz doświadczane trudności. W pełni zadowolonych ze swojej pracy było $92 \%$ uczestników badań. Wskazuje to na właściwe rozpoznanie potrzeb badanych osób oraz dopasowanie miejsca odbywania stażu do ich możliwości i preferencji. Nie bez znaczenia jest też na pewno to, że wszystkie badane osoby były zatrudnione legalnie i miały pewność trwania zatrudnienia przez sześć miesięcy. W ramach stażu jego uczestnicy otrzymywali wynagrodzenie w wysokości najniższej pensji krajowej (ok. 1750 brutto), pomimo tego ponad $87 \%$ badanych stwierdziło, że ich dochody są zadowalające. Można stwierdzić, że wskazuje to na niskie oczekiwania finansowe badanych osób, ale jednocześnie na świadomość realiów rynku pracy, na którym nawet wykształcenie wyższe (które miało $45 \%$ badanych) nie daje gwarancji otrzymania dobrze płatnej pracy. Badani wyrażali także optymizm co do swojego przyszłego zatrudnienia - $75 \%$ z nich było przekonanych, że w przyszłości będą mieć dobrą pracę. 
Uczestnicy dzięki pracy czuli się bardziej samodzielni (67\%). Jednocześnie $63 \%$ badanych sądziło, ze niesłyszący i słabosłyszący muszą być w pracy lepsi niż osoby słyszące, żeby ją utrzymać. Respondenci stwierdzali także, że ich praca jest zgodna z posiadanym wykształceniem i zainteresowaniami oraz mogą w niej wykorzystać w pełni swoje umiejętności (po $85 \%$ badanych). Jednocześnie połowa badanych osób (50\%) wyrażała przekonanie, że ich kompetencje są zbyt niskie i powinni podnieść swoje kwalifikacje - sądziło tak $84 \%$ badanych.

Kolejna grupa pytań dotyczyła trudności badanych osób w komunikacji w środowisku pracy. Wyniki wskazują, że ponad połowa badanych doświadcza w tym zakresie istotnych trudności: mają problemy w komunikacji ze współpracownikami (58\%), wyrażają lęk, że nie usłyszą jakiegoś ważnego komunikatu (53\%) i czują się niedoinformowani (58\%). Nieco rzadziej badani sygnalizują, że nie rozumieją poleceń przełożonych (47\%), a $40 \%$ ukrywa to, że ma problemy ze słuchem.

Zasadniczą część badania stanowiły pytania dotyczące jakości relacji społecznych doświadczanych w środowisku pracy. Ponad połowa (62\%) czuła się niedoceniana przez przełożonych. Analiza wyników wskazuje także na trudności doświadczane w relacji ze współpracownikami: tylko 37\% badanych twierdzi, że praca pozwala na nawiązywanie nowych znajomości, zaś ponad połowa badanych osób doświadcza w pracy uczucia samotności i ma poczucie, że inne osoby je obgadują (po 53\% odpowiedzi). Osoby niesłyszące i słabosłyszące czują także, że ich kompetencje uznawane są za niewystarczające przez współpracowników (56\%). Tylko nieco więcej niż jedna trzecia badanych (36\%) czuje się traktowana tak samo jak osoby słyszące.

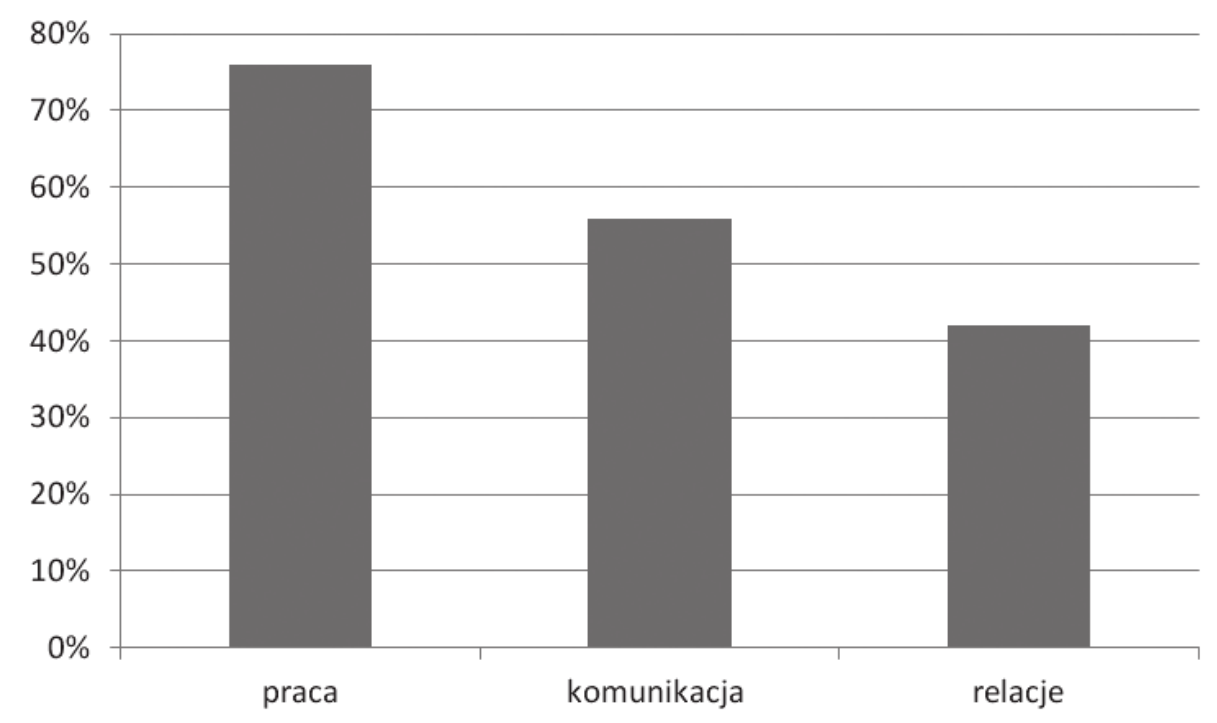

Wykres 1. Wyniki w zakresie oceny pracy zawodowej, jakości komunikacji oraz relacji interpersonalnych w środowisku pracy

Źródło: opracowanie własne. 
Podsumowując wyniki badań w analizowanych trzech sferach, można stwierdzić, że badane osoby wysoko oceniają pracę samą w sobie (76\%): możliwość jej podjęcia, poziom wynagrodzenia, dostosowanie jej do wykształcenia, zainteresowań i kompetencji. Badane osoby doświadczają jednak dużych trudności w zakresie komunikacji (ogólny poziom zadowolenia z komunikacji wynosi $56 \%$ ), w tym szczególnie ze współpracownikami. Ogólny poziom zadowolenia z relacji społecznych doświadczanych w pracy także jest niski i wynosi $42 \%$. Wyniki te zaprezentowano na wykresie 1 .

\section{Implikacje praktyczne}

Przedstawione wyniki mają istotne implikacje dla profesjonalistów pracujących z osobami niesłyszącymi i słabosłyszącymi. Wskazują przede wszystkim na wysoką motywację badanych osób $\mathrm{z}$ wadą słuchu do podejmowania pracy. Wyników tych nie można oczywiście uznać za reprezentatywne dla całej populacji osób niesłyszacych i słabosłyszących, ponieważ - jak zaznaczono w opisie grupy badawczej - poziom wykształcenia w badanej grupie był stosunkowo wysoki, a badane osoby zgłosiły się także samodzielnie do projektu „Przełamując ciszę”, co pokazuje ich aktywność i chęć zmiany sytuacji życiowej. Jednocześnie odpowiedzi badanych osób pokazują, że praca zawodowa ma dla nich wyjątkowe znaczenie, przy czym nie wiąże się ono wyłącznie z korzyściami materialnymi, lecz także z pragnieniem własnego rozwoju i potrzebą działania.

Szczególnie niepokojące są wyniki wskazujące na dużą izolację społeczną badanych osób. Pomimo tego, że ponad $80 \%$ badanych w komunikacji wykorzystuje mowę, a nie język migowy, doświadczają oni bardzo dużego poczucia osamotnienia i izolacji, nie czują się włączeni w zespół pracowników. Z całą pewnością metodą przezwyciężenia tej sytuacji nie jest tylko doradztwo zawodowe czy coaching skierowany do osób z wadą słuchu. Konieczne - a prawie zupełnie nieobecne w polskiej rzeczywistości - są działania skierowane do współpracowników osób niesłyszących i słabosłyszących, przedstawiające charakter trudności doświadczanych przez tę grupę i sposoby ich przezwyciężania (np. systematyczne stosowanie zasad poprawnej komunikacji: mówienie z twarzą zwróconą zawsze w kierunku osoby niesłyszącej/słabosłyszącej, powtórzenie wypowiedzi, jeśli jest to konieczne, lub korzystanie w komunikacji z pisma). Jeśli głównym narzędziem komunikacji jest dla osoby niesłyszącej język migowy, współpracownicy powinni nauczyć się jego podstaw tak, aby móc prowadzić proste rozmowy. Ważna jest także postawa życzliwości i realna chęć włączenia osoby niesłyszacej czy słabosłyszącej nie tylko we wspólne wykonywanie zadań wynikających z pracy, lecz także w życie społeczne w miejscu pracy, np. poprzez wspólne spędzanie przerw, dzielenie się informacjami osobistymi, utrzymywanie relacji towarzyskich również poza miejscem pracy. Bardzo pomocny może 
się okazać mentor - słysząca osoba odpowiedzialna za wprowadzenie osoby z wadą słuchu w środowisko pracy i towarzysząca jej rozwojowi (Foster, MacLeod, 2004; Allen, Rawlings, Schildroth, 1989). Jednocześnie oznacza to, że poprawa warunków pracy osób niesłyszących i słabosłyszących nie musi się wiązać z dużymi nakładami finansowymi (podwyżkami czy kosztownym dostosowaniem stanowisk pracy), ponieważ w wielu sytuacjach kluczową formą poprawy jest - wymagająca jedynie kosztów społecznych i inwestycji czasowych - zmiana rodzaju relacji społecznych między niesłyszacym czy też słabosłyszącym pracownikiem a jego współpracownikami i przełożonymi.

\section{Bibliografia}

Allen, T.E., Rawlings, B.W., Schildroth, A.N. (1989). Deaf Students and the School to Work Transition. Baltimore: Paul H. Brooks Publishing Company.

Barczyński, A., Radecki, P. (2008). Identyfikacja przyczyn niskiej aktywności zawodowej osób niepetnosprawnych. Raport z badań. http://www.pfron.org.pl/ftp/dokumenty/EQUAL/Kluczowa_rola_gminy/Identyfikacja_przyczyn_niskiej_aktywnosci_zawodowej_ON_raport_z_badan.pdf (dostęp: 12.09.2014).

Brzezińska, A.I., Piotrowski, K. (2008). Wyznaczniki satysfakcji z wykonywanej pracy osób z ograniczona sprawnościa: kompetencje i relacje. Warszawa: Wydawnictwo SWPS Academica.

Domagała-Zyśk, E. (2010). Postrzeganie predyspozycji zawodowych osób z uszkodzeniami słuchu. W: D. Bis, J. Ryś (red.), Szkolnictwo i kształcenie zawodowe- wybrane aspekty (s. 235265). Lublin: Studio Format.

Domagała-Zyśk, E. (2013). Współczesne rozwiązania w zakresie wspierania zatrudnienia osób z uszkodzeniami słuchu. W: B. Sidor-Piekarska (red.), Kompetentne wspieranie osób z niepełnosprawnościa (s. 147-169). Lublin: Wydawnictwo KUL.

Domagała-Zyśk, E. (2014). Deaf and hard of hearing graduates on the contemporary work market. W: F.W. Wawro (red.), The Selected Areas of Educational and Social Work under Contemporary Conditions (s. 239-256). Lublin: Wydawnictwo KUL.

Dunaj, M. (2014). Osoby głuche na rynku pracy. W: M. Świdziński (red.), Sytuacja osób głuchych w Polsce. Raport zespołu ds. g/Gluchych przy Rzeczniku Praw Obywatelskich (s. 89-103). Warszawa: Biuro Rzecznika Praw Obywatelskich.

Foster, S., MacLeod, J. (2004). The role of mentoring relationships in the career development of successful deaf persons. Journal of Deaf Studies and Deaf Education, 9, 4, 442-457.

Geyer, P.D., Schroedel, J.G. (1999). Conditions influencing the availability of accommodations for workers who are deaf or hard-of-hearing. Journal of Rehabilitation, 2, 42-50.

Gorczycka, E. (2000). Postawy pracodawców wobec osób niepełnosprawnych jako aspekt otwarcia miasta na ich potrzeby. W: J. Lewandowski (red.), Ergonomia niepetnosprawnym. Środowisko pracy (s. 45-51). Łódź: Wydawnictwo PŁ.

Konwencja nr 159 Międzynarodowej Organizacji Pracy dotycząca rehabilitacji zawodowej i zatrudnienia osób niepełnosprawnych z dnia 20 czerwca 1983 r. (Dz.U. z dnia 18 marca 2005 r.).

Kowalik, S. (2007). Psychologia rehabilitacji. Warszawa: WAiP.

Kramer, S.E. (2008). Hearing impairment, work, and vocational enablement. International Journal of Audiology, 47 (Suppl. 2), 124-130.

Maciejska-Roczan, K. (2011). Osoby niesłyszące i słabosłyszące. W: B.M. Kaczmarek (red.), Zbiorczy raport $z$ diagnozy świadczonych ustug $w$ zakresie rehabilitacji społecznej dla osób niepetnosprawnych w Polsce (s. 21-41). Warszawa: Koalicja na Rzecz Osób z Niepełnosprawnością. 
Majewski T. (2005). Bariery mentalne i emocjonalne w zatrudnianiu osób niepełnosprawnych na otwartym rynku pracy. Aktywizacja Zawodowa Osób Niepetnosprawnych, 4(4), 75-80.

Majewski, T. (2006). Praca zawodowa - ważny wyznacznik jakości życia osób niepełnosprawnych. W: Z. Palak (red.), Jakość życia osób niepetnosprawnych i nieprzystosowanych społecznie (s. 52-57). Lublin, Wydawnictwo UMCS.

Majewski, T. (2007). Rodzaj niepełnosprawności a potrzeby osób niepełnosprawnych w zakresie aktywizacji zawodowej. W: Potrzeby osób niepetnosprawnych w zakresie aktywizacji zawodowej. Materiaty konferencyjne. Opracowanie zbiorowe (s. 26-45). Warszawa: Krajowa Izba Gospodarczo-Rehabilitacyjna.

Mikulski, J., Kurzynowski, A. (2004). Rehabilitacja i zatrudnienie osób niepetnosprawnych na otwartym rynku pracy. Warszawa: CEBRON-SGH.

Morgeson, F.P., Humphrey, S.E. (2006). The Work Design Questionnaire (WDQ): Developing and validating a comprehensive measure for assessing job design and the nature of work. Journal of Applied Psychology, 91(6), 1321-1339.

Osoby niepetnosprawne na rynku pracy w 2011 roku (2012). Główny Urząd Statystyczny. http:// stat.gov.pl/cps/rde/xbcr/gus/pw_osoby_niepelnosprawne_na_rynku_pracy_w_2011.pdf (dostęp: 12.09.2014).

Piekot, T. (2011). Raport z badań zogniskowanych - tożsamość zawodowa osób głuchych i ich problemy na rynku pracy. Wrocław: Dobre Kadry.

Punch, R., Creed, P.A., Hyde, M.B. (2005). Predicting Career Development in hard-of-hearing adolescents in Australia. Journal of Deaf Studies and deaf Education, 10, 2, 146-160.

Radecki, P. (2007). Identyfikacja potrzeb osób niepetnosprawnych w zakresie aktywizacji zawodowej-raport z badań kwestionariuszowych. Warszawa: Krajowa Izba Gospodarczo-Rehabilitacyjna.

Sobczak, W. (2007). Postawy pracodawców wobec potrzeb osób niepełnosprawnych. W: Potrzeby osób niepetnosprawnych w zakresie aktywizacji zawodowej. Materiały konferencyjne. Opracowanie zbiorowe (s. 7-25). Warszawa: Krajowa Izba Gospodarczo-Rehabilitacyjna.

Świdziński, M. (red.). (2014). Sytuacja osób głuchych w Polsce. Raport zespołu ds. g/Gtuchych przy Rzeczniku Praw Obywatelskich. Warszawa: Biuro Rzecznika Praw Obywatelskich.

Szczupał, B. (2004). Bezrobocie osób niepełnosprawnych jako zjawisko społeczne i edukacyjne. W: G. Dryżałowska, H. Żuraw (red.), Integracja społeczna osób niepełnosprawnych. Warszawa: Wydawnictwo Akademickie Żak.

Ustawa z dnia 27 sierpnia 1997 r. o rehabilitacji zawodowej i społecznej oraz zatrudnianiu osób niepetnosprawnych (Dz.U. z 2008 r., Nr 14, poz. 92).

Zadowolenie osób niepetnosprawnych z pracy. Raport TNS OBOP dla Państwowego Funduszu Rehabilitacji Osób Niepetnosprawnych (2010). http://www.pfron.org.pl/ftp/dokumenty/Badania_i_analizy/Zadowolenie_osob_niepelnosprawnych_z_pracy_raport_2010.pdf (dostęp: 12.01.2014).

\section{RELACJE SPOŁECZNE OSÓB NIESŁYSZĄCYCH I SŁABOSŁYSZĄCYCH W ŚRODOWISKU PRACY}

\section{Streszczenie}

Satysfakcja z pracy zawodowej zarówno w przypadku osób sprawnych, jak i niepełnosprawnych wiąże się nie tylko z korzyściami finansowymi czy też prestiżem danego zawodu, lecz także z czynnikami społecznymi, takimi jak atmosfera w pracy, relacje interpersonalne, poczucie przynależności i bezpieczeństwa. W sytuacji osób niesłyszących i słabosłyszących nie jest łatwo osiągnąć te cele, ponieważ wymaga to przezwyciężenia bariery komunikacyjnej.

Celem artykułu jest określenie jakości relacji społecznych w środowisku pracy zawodowej osób niesłyszących i słabosłyszących. Po przedstawieniu sytuacji tej grupy na współczesnym rynku pracy i uzasadnieniu znaczenia, jakie mają dla nich pozytywne relacje społeczne, autorka 
prezentuje wyniki badań własnych. Zostały one przeprowadzone wśród 31 niesłyszących i słabosłyszących pracowników. Wyniki pokazują wysoki poziom motywacji do podejmowania pracy zawodowej oraz wysoki poziom ogólnej satysfakcji z pracy. Zarazem jednak ukazują duże trudności w zakresie komunikacji i konsekwentnie niski poziom satysfakcji z relacji społecznych w środowisku pracy. Wskazują na konieczność dalszych badań tego zjawiska oraz podejmowania przez doradców zawodowych i trenerów działan praktycznych w celu zmiany tej sytuacji.

Slowa kluczowe: niesłyszący, słabosłyszący, praca, satysfakcja z pracy, bariery komunikacyjne

\section{SOCIAL RELATIONSHIPS OF DEAF AND HARD-OF-HEARING PEOPLE IN THE WORK ENVIRONMENT}

\section{Abstract}

In the case of both nondisabled people and people with disabilities, satisfaction from one's career is connected not only with financial benefits or the prestige of a given profession, but also with social factors, such as atmosphere at work, interpersonal relationships or a feeling of membership and security. These goals are difficult to achieve for deaf and hard-of-hearing people as this would require that the communication barrier be overcome.

The purpose of the article is to define the quality of social relationships in the work environment of deaf and hard-of-hearing people. The Author presents this group's situation in the modern labor market and justifies the importance of positive social relationships to this group; then she presents the findings of her own study. It was conducted among 31 deaf and hard-of-hearing employees. The findings show a high level of motivation for taking up employment and a high level of overall job satisfaction. At the same time, however, they show significant difficulties in communication and, in consequence, a low level of satisfaction from social relationships in the work environment. The findings indicate that further research on this phenomenon is needed and that practical actions need to be undertaken by career counselors and coaches in order to change this situation.

Key words: deaf people, hard-of-hearing people, work, job satisfaction, communication barriers 